Article

\title{
A Human Resources Perspective on Responsible Corporate Behavior. Case Study: The Multinational Companies in Western Romania
}

\author{
Ciprian Obrad ${ }^{1, *(1)}$ and Vasile Gherheș ${ }^{2}$ (1) \\ 1 Department of Sociology, West University of Timișoara, Timișoara 300223, Romania \\ 2 Department of Communication and Foreign Languages, Politehnica University of Timișoara, \\ Timișoara 300006, Romania; vasile.gherhes@upt.ro \\ * Correspondence: ciprian.obrad@e-uvt.ro; Tel.: +40-723-525-454
}

Received: 18 January 2018; Accepted: 2 March 2018; Published: 7 March 2018

\begin{abstract}
This article aims to show the extent to which socially responsible Human Resource Management practices are implemented in multinational companies. As more recent studies highlight, the manner in which companies in Romania presently comprehend the social responsibility of their actions is mostly aimed towards the social component of the outer environment in which they function and less towards their own employees. In Romania, at the moment, there are only a few studies that catalogue the efforts made by companies in order to become more responsible towards their employees, or in other words, studies that present Corporate Social Responsibility (CSR) within its relationship with Human Resources Management (HRM). The research method we used for our case study was the semi-structured interview, applied on 32 respondents from the multinational companies carrying out their activities in the automotive sector in western Romania. Our study shows that multinational companies from the automotive sector are aware that CSR effects a series of long-term advantages, either externally-enhancing the company's reputation and consolidating its brand as employer, its competitive advantage on the market, its media visibility—or internally—-fostering an organizational culture that may generate greater engagement from its own employees, and financial advantages.
\end{abstract}

Keywords: social responsibility; human resources; sustainability

\section{Introduction}

At the beginning of the decade, the ISO 26000 standard for social responsibility and sustainable development, launched at the end of 2010, defined Corporate Social Responsibility thusly: "the responsibility of an organization for the impacts of its decision and activities on society and the environment, through transparency and ethical behavior that contribute to sustainable development, takes into account the expectation of stakeholders, is in compliance with applicable law and consistent with international norms of behavior, is integrated throughout the organization and practices in its relationship" [1].

According to a more recent definition by the European Commission, Corporate Social Responsibility (CSR) is a process for companies to integrate social, environmental, ethical, and human rights concerns into their operations and core strategy, in close collaboration with their stakeholders [2].

It is worth mentioning that if, at the beginning, the concept of CSR referred only to social or environmental concerns, at the moment it encompasses all types of impact that a company may have on society. The social component of CSR refers to two dimensions: an external one in which organizations can affect stakeholders as business partners or suppliers and strive to become more involved in the community and participate in the social costs of whatever affects the community, and an internal dimension in which companies are responsible towards their own employees, maintaining 
a fair attitude towards the latter's problems, aspirations, and quality of life. Employees are not just rank-and-file stakeholders; they are the most important stakeholders in a company's activity. A crucial characteristic of the most sustainable corporations in the world is the way in which they act responsibly towards their own employees, on the one hand, and the way in which they respond to the needs of society, on the other. The responsibility of their activities is reflected internally, as well, in the values that these companies foster, values that are adapted to the social and physical environment in which the company carries out its activities.

The companies' social responsibility towards their own employees-the working and professional conditions that they offer-appeared collaterally, in the context in which the mass media, the NGOs, and the consumers were putting pressure on companies to become involved in socially responsible behaviors. This pressure became a mechanism to encourage organizations to improve the relationship with their own employees [3].

The connection between CSR and HRM (Human Resources Management) is illustrated by recent and quite extensive literature.

From a traditional perspective, there have been several attempts to define the concept of corporate environmental performance which lies at the basis of CSR. This performance was tied to a certain development of human resources in companies, especially the training employees acquire [4]. Theories based on organizational resources back this point of view (resource-based perspective). According to this perspective, there are tangible as well as intangible organizational resources that a company can update in order to achieve corporate performance. Tangible resources refer to the company's financial reserves, its equipment, and its stock; whereas intangible resources refer to employees, the in-house culture, their training, their engagement, and their loyalty. They manner in which the organization manages these resources and skills, including its human resources, determines its performances and its social reputation [5].

There is an instrumental perspective on the relationship between CSR and HRM, according to which the CSR reputation and practices of a company can be used to attract, retain, and motivate employees. That is to say, CSR activities can be considered a means of improving recruitment practices in order to attract the most talented candidates, to motivate employees, and to enhance the company's commitment towards its own organizational objectives [6].

CSR can have positive effects on employees' motivation, morale, commitment, and loyalty to the firm. Socially responsible employment practices such as training opportunities, a clean and safe working environment, fair wages, health and education benefits for their employees and their families, flexible work hours and job sharing, can bring direct benefits to a firm by increased morale and productivity while reducing absenteeism and staff turnover.

Also, "firms with a good social responsibility reputation may improve relations with external actors such as customers, investors, bankers, suppliers and competitors. They may also attract better employees or increase current employee's motivation and morale as well as their commitment and loyalty to the firm, which in turn may improve financial outcomes" [7].

According to a conflictual perspective on the inter-relationship between CSR and HRM, there is a host of interests that may occasionally be difficult to reconcile. Conflict resolution entails negotiation processes and making a decision is heavily reliant on the parties involved, their moral and personal values, and on existing obligations as perceived by the different groups of stakeholders. The relationship between CSR and HRM is not always a positive one [8,9].

From an integrative perspective on the connection between CSR and HRM, CSR activities impact not only the employees' degree of engagement and motivation, but also the organizational identity. The employees practically evolve and become responsible corporate citizens.

On the other hand, the interests between different stakeholders can be realigned by creating common values, which can then become embedded in the ethical layer of the relational contract where both employer and employees espouse common, moral, and mutual obligations towards one another but also towards society [10]. These moral commitments can be promoted and can become regular 
policies of human resources departments, through a process of secondary workplace socialization for the employee. Thus, all stakeholders' interests are integrated and win-win situations are effected. This perspective stems from the psychological contract theory [11].

Beyond these definitions and perspectives, the way in which companies from Romania understand the social responsibility of their actions is mostly aimed at the external, social component of the environment in which they carry out their activities, rather than internally, as recent studies suggest.

CSR Media carried out a study in 117 companies from Romania, between 2016 and 2017, exploring the managers' and CSR specialists' perceptions on the dynamics and challenges in the field [12]. The answers to the question "Which of the following options do you consider to be the most appropriate to define social responsibility?" show that $85 \%$ of the of the responding companies define social responsibility as involvement in the community, $65 \%$ as sustainable business strategy, $59 \%$ as business ethics, $31 \%$ as the responsible management of the supplier chain, $29 \%$ as significant interactions with the stakeholders, $27 \%$ as philanthropy, and $18 \%$ as risk management.

Romanian companies become involved in CSR as a PR strategy, because it generates recognition and visibility, and facilitates the development of the brand. Companies involve their employees in CSR actions oriented externally towards the community, but they should also be oriented internally.

In another study called Romania CSR Index 2017 [13] which assessed 100 Romanian companies carrying out various CSR projects, according to an index containing 43 indicators organized in 9 categories, the main conclusion is relatively similar. The first CSR categories where the companies channel their energy are the economic impact of their activity, the involvement in the community, marketing, and creating awareness. However, we would like to point out that this study does not include the employee dimension. It remains a category that has yet to fully integrate with the local comprehension of the CSR concept.

The following article aims to fill in this gap starting from this Romanian reality as well as from the fact that up until now there has been no empirical study in Romania that might summarize the organizations' efforts of becoming more responsible towards their own employees.

Doubtlessly, a history of responsible, social involvement generates long-term benefits by consolidating the brand and creating a good reputation for the organization $[6,7,14,15]$. Thus, some companies became solely motivated by these PR benefits losing sight of their own employees and their needs. Also, this reality does not belong solely to the past; it is still quite a common occurrence in the Romanian corporate environment. When the employees' needs are disregarded, CSR becomes a mere PR (public relations) function (see Figure 1).

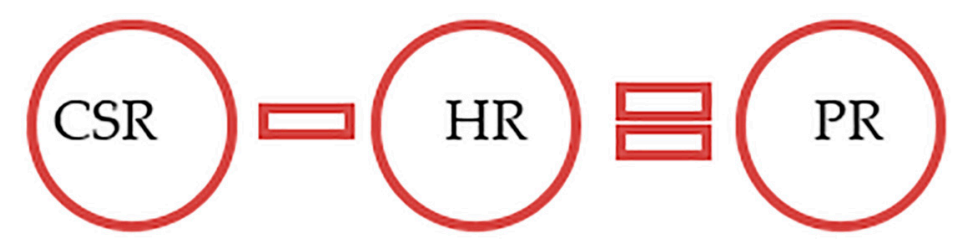

Figure 1. The concept of reduced Corporate Social Responsibility (CSR).

A company's social responsibility encompasses vigilant interest in contributing to the "common good" [16], not just reaching out towards the surrounding community, but also reaching towards its own human resources. A socially responsible company, especially in the modern sense of the concept, is intently preoccupied with its employees, their health, their work safety; it provides the best conditions for their activity and professional development. In this case, the concept of CSR encompasses new dimensions (see Figure 2).

Basically, the old concept of CSR acquires a new dimension: that of internally-oriented responsibility, rather than one aimed only outwards (CSR without HR is PR). Without this dimension, the companies' responsibility is incomplete, acting as a mere PR function. That is to say, the companies' responsibility has to encompass all stakeholders. The ethical principle of responsibility cannot 
discriminate and cannot function only partially, favoring just some groups of stakeholders that are impacted by the organizations' activity.

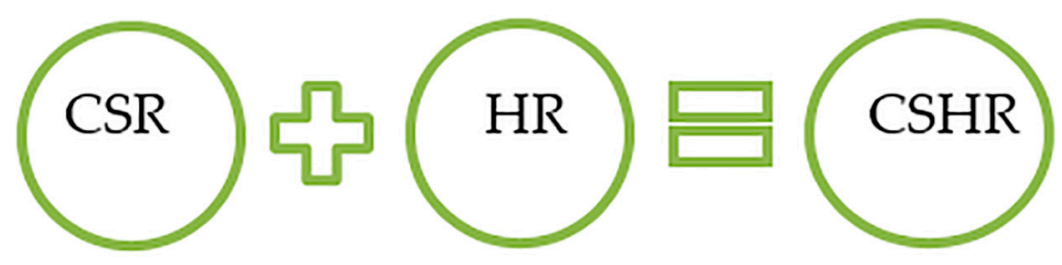

Figure 2. The concept of extended CSR.

The concept of extended CSR is conditioned by another concept, that of sustainability, or sustainable/durable development. This concept was first introduced in 1987, by a report published by the Brundtland Commission (also known for a long time as WCED-World Commission on Environment and Development, whose role was to oversee the nations' united efforts for a common, durable development). According to this commission, sustainability, or durable business development, means "ensuring that it meets the needs of the present without compromising the ability of future generations to meet their own needs" [17]. This is one of the first attempts made to clarify the term, and it remains just as relevant today. The concept emphasizes the fact that economic development, and safeguarding social relationships and natural resources must take place simultaneously. In other words, sustainability incorporates ethical aspects that should upgrade corporate conscience towards a durable, long-term vision, in which economic development should take into account its impact on the opportunities of future generations.

Dyllick and Hockerts [18] define corporate sustainability as "meeting the needs of a company's direct and indirect stakeholders (employees, clients, pressure groups, communities, etc.), without compromising its ability to meet the needs of future stakeholders as well". A growing number of stakeholders, such as citizens, activists, consumers, police officers, investors, and NGOs have militated over the years for organizations to assume an increasingly extended social responsibility. More or less forced by the circumstances, many of these companies have adopted a new method of managing their activities, at the same time providing informational transparency. Sustainable companies safeguard the environment, society, and their own employees. Their human resources departments play a pivotal role in attracting the suitable personnel and training them insofar as social responsibility and sustainability are concerned. That is to say, the HR generates and enhances the CSR [3].

On the other hand, once efficiently implemented, social responsibility activities may significantly influence how companies attract, motivate, train, and retain their employees. From this point of view, the CSR impacts the HR (see Figure 3).

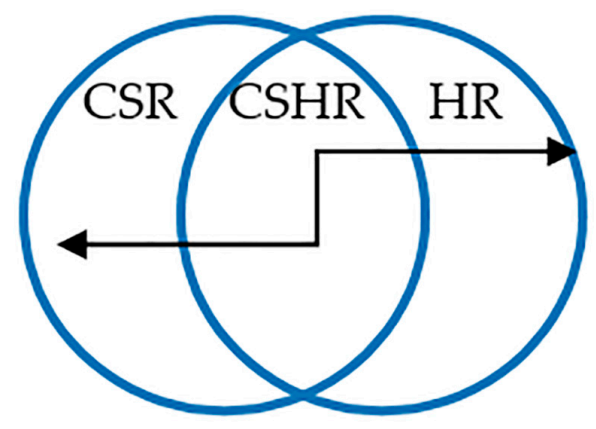

Figure 3. The mutual influence between CSR and Human Resources Management (HR).

In order to emphasize the close connection between HR and CSR, Elaine Cohen [19] points out the role of the Human Resources Department, and that of HR management: 
- To ensure that all employees adhere to certain values, and ethical behavior, in accordance with the company's policy;

- To ensure the CSR's transparency by informing their employees with regards to internal and external actions;

- $\quad$ To evaluate CSR reports;

- To adopt a recruitment strategy in accordance with the company's values and social responsibility principles;

- To ensure and foster the employees' engagement with the company;

- To ensure a suitable corporate climate which can allow the business to succeed in a responsible manner.

According to a study conducted in 2009 [20], by the Canadian company Strandberg Consulting, Human Resources specialists can follow a ten-step checklist in order to integrate social responsibility (see Table 1). As a business partner, the Human Resources Department must facilitate, coordinate, and constantly improve CSR practices.

Table 1. Checklist for integrating CSR in the human resources strategy (Source: Strandberg Consulting).

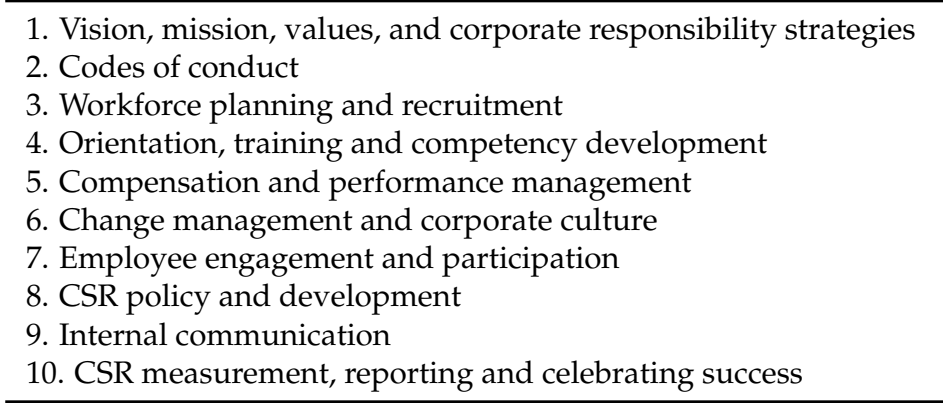

Corporate social responsibility has revealed its complex dimensions in big organizations which exist on several markets and in diverse cultural contexts, that is, multinational companies. "Engaging employees represents a crucial element, consolidating local communities is important, protecting the environment is vital, and building trust among stakeholders ensures an efficient risk management and opportunity identification. Human resources play a fundamental role in fostering a beneficial corporate climate, and in designing profitable practices, thus allowing the company to be responsibly successful" [21].

As with any import of institutional know-how, novel forms were borrowed first, before they started generating their own content. Initially, a great number of companies adopted CSR strategies, responsible practices, and started becoming involved in outreach programs aiming to consolidate their own image and their own position on the market, rather than to meet the needs manifested by the stakeholders. In other words, commercial reasons rather than ethical ones predominated.

Following the concerns for the content and the essence of the CSR phenomenon (which means constant concern, with ethical foundation, for the good of others), CSR strategies have emerged, aiming at the long-term welfare of social communities, of their own employees, of environmental protection on the one hand, and on the other embedding the philosophy of sustainable development [22].

In previous years, there have been several studies in Romania examining the presence of strategical CSR projects in native companies and evincing the existence of dedicated strategies [23,24]. At the same time, there have been studies underscoring the involvement of an increasing number of companies in CSR activities [25-30], the diversity and originality of projects, as well as an increasing interest in social responsibility programs [31]. In academic literature, there were studies and treatises $[19,32]$ that emphasized the contribution of the academic environment in developing corporate social responsibility, but also the population's expectations insofar as recipients of CSR programs carried out by companies. Nevertheless, the social dimension of responsibility is oriented more often outside the companies. 
This article sets off from a semi-structured interview with respondents from various multinational companies, and its intention is to research to what degree employee-oriented responsibility is a part of the manner in which the CSR concept is implemented in the Romanian, organizational environment. We verified the dimensions in which socially-responsible human resources practices manifest themselves, we transcribed them in indicators, and then we collected the data from the multinational companies belonging to the automotive sector in western Romania.

\section{Research Methodology}

In order to capture the manner in which social responsibility intertwines with some human resources practices within companies and how a greater corporate sustainability results from this convergence, we carried out research among multinational companies in the automotive sector from Western Romania (the Timiș County). We chose to study what happens in multinational organizations in Romanian because it was these organizations that institutionally imported the concept of CSR in local organizational culture. According to our previous studies, multinational companies are the most likely to manifest socially responsible behaviors.

At the same time, we chose the West of the country, because Timișoara (the capital city of Timiș County) is the first logistical and industrial market to establish itself after the 1990s. According to Forbes Romania, in 2015 and 2016, Timișoara was considered the best city for business. After, Bucharest, the capital of Romania, Timișoara was the most dynamical region in terms of labor market. The main economic fields in Timișoara remain the automotive industry and the IT sector.

We decided to include the automotive multinational companies from western Romania in the case study starting from the premise that, if social responsibility in these companies includes an internal social component oriented towards human resources, then it is most likely present in these organizations rather than anywhere else. Also, the automotive sector has gone through an intense development, to the point that a cluster was created in this area. The company selection was made according to the main field of activity, from a database of all economic agents from Timis County. The total population of relevant companies consisted of 45 multinational businesses with a large number of employees. In order to collect our data, we employed the semi-structured interview, applied to human resources specialists from departments inside these companies. We chose this method due to the fact that some of the companies do not make their CSR reports public, and the information regarding the social internal dimension (the employees) is not detailed. Following our request, the interview guide was filled in by 32 representatives from these companies.

Starting from the idea that the employees represent one of the most important stakeholders of social responsibility, as illustrated by the extended HRCSR concept, our study attempted to identify to what extent companies manifest social responsibility towards their employees [33-35]. After an analysis of similar studies $[15,29]$ on the indicators of internal social responsibility in companies, we introduced 23 indicators in our interview guide, grouped in five dimensions, as follows:

- Working conditions-5 indicators (Table 2);

- Health and workplace safety-5 indicators (Table 3);

- Professional development and training-3 indicators (Table 4);

- Employees' rights-5 indicators (Table 5);

- Internal communication-5 indicators (Table 6).

We proposed the same scale for opinion measurement on all indicators, thus trying to identify the extent to which the elements that interested us were present in the companies taking part in the study. The answer variants were "to a very high degree", "to a high degree", "to an adequate degree", "to a small degree", "to a very small degree".

In order to compare the 23 indicators, we rated each answer variant as follows: 5 points for "to a very high degree", 4 points for "to a high degree", 3 points for "to an adequate degree", 2 points for "to a small degree", and 1 point for "to a very small degree". Therefore, for each indicator, regardless 
of the dimension to which it is allocated, the maximum possible score is of 160, resulting from the number of companies (32), and the maximum scale score, for the answer "to a very high degree" (5). This is the score against which we measured the analysis of our recorded data for each indicator.

We also used the following indices in order to analyze and compare the scores, as follows (Table 2).

Table 2. Methodology score indices.

\begin{tabular}{|c|c|c|}
\hline & Scores & Gross Total Score \\
\hline 1. & Maximum score & The theoretical number if each company were to score 5 points for each indicator \\
\hline 2. & Gross total score & $\begin{array}{l}\text { The cumulative score, resulting from adding the answers for all companies, for } \\
\text { each indicator }\end{array}$ \\
\hline 3. & Relative score $(\%)$ & Score obtained by measuring the gross total score against the maximum score \\
\hline 4. & $\begin{array}{l}\text { The mean } \\
\text { aggregate score }\end{array}$ & $\begin{array}{l}\text { The mean of the aggregate scores obtained by each company included in the } \\
\text { study, for each of the research dimension }\end{array}$ \\
\hline 5. & Coverage rate $(\%)$ & $\begin{array}{l}\text { The degree to which each social responsibility dimension is fulfilled within the } \\
\text { analyzed companies (a 100\% coverage rate shows that organizations manifest a } \\
\text { high social responsibility towards a certain dimension (employee working } \\
\text { conditions, for instance), or that the phenomenon expressed by a certain } \\
\text { dimension is totally present). }\end{array}$ \\
\hline
\end{tabular}

\section{Results}

Starting from the above-mentioned methodology, we calculated the final scores for each indicator of the dimensions we studied. Then, by comparison, we emphasized where the companies in the study situate themselves according to these indicators. In what follows we would like to present the situation for the five dimensions:

\subsection{Indicator Set for the Working Conditions Dimension}

From the point of view of the mean aggregate score for the working conditions dimension (calculated as a mean of the scores obtained by each of the companies included in the study), the companies from the automotive sector obtained a score of 18.03 points, which represents a $72.12 \%$ coverage of the maximum potential.

On the other hand, if we are to analyze the level of indicators that make up this dimension (see Table 3), the companies under scrutiny scored best when it comes to optimal working conditions for employees (approximately $70 \%$, a score of 111 , in first place). The companies in our study registered the lowest score $(47 \%)$ when it comes to working conditions for employees with disabilities (77 points, fifth place).

Table 3. Scores for working conditions indicators.

\begin{tabular}{clccc}
\hline & \multicolumn{1}{c}{ Dimension Indicators } & $\begin{array}{c}\text { Gross Total } \\
\text { Score }\end{array}$ & $\begin{array}{c}\text { Relative } \\
\text { Score (\%) }\end{array}$ & $\begin{array}{c}\text { Ranking } \\
\text { Indicator }\end{array}$ \\
\hline 1. $\quad \begin{array}{l}\text { There are procedures in the company that facilitate a } \\
\text { flexible work program for certain categories of employees. }\end{array}$ & 95 & 59.37 & 3 \\
\hline 2. & $\begin{array}{l}\text { There are provisions for telecommuting in the company } \\
\text { (home office, etc.). }\end{array}$ & 91 & 56.87 & 4 \\
\hline 3. & Employees can organize their own breaks & 97 & 60.62 & 2 \\
\hline $4 . \quad \begin{array}{l}\text { The company ensures optimal working conditions for its } \\
\text { employees. }\end{array}$ & 111 & 69.37 & 5 \\
\hline 5. & There are provisions for employees with disabilities & 77 & 48.12 & $100 \%$ \\
\hline
\end{tabular}




\subsection{Indicator Set for the Health and Work Safety Dimension}

Within this dimension, the companies we have studied obtained a mean aggregate score of 20.62, meaning an $80 \%$ coverage of the maximum possible score (see Table 4). Out of the indicators that make up the health and work safety dimension, the most serious concerns were manifested for employees' safety and adequate sanitation facilities (both indicators scoring at 117, namely a relative score of $73.12 \%)$. The lowest registered score is generated by "disease and serious health risk prevention programs" which appears only in a little over half of the answers here.

Table 4. Scores registered for the health and work safety dimension.

\begin{tabular}{llccc}
\hline & \multicolumn{1}{c}{ Dimension Indicators } & $\begin{array}{c}\text { Gross Total } \\
\text { Score }\end{array}$ & $\begin{array}{c}\text { Relative } \\
\text { Score (\%) }\end{array}$ & $\begin{array}{c}\text { Ranking } \\
\text { Indicator }\end{array}$ \\
\hline 1. & There are provisions for employee work safety in the company. & 117 & 73.12 & 1 \\
\hline 2. & There is a medical practice in the company. & 92 & 57.50 & 3 \\
\hline 3. & There are adequate sanitation facilities in the company. & 117 & 73.12 & 1 \\
\hline 4. & $\begin{array}{l}\text { Work safety training is carried out in the company above the } \\
\text { minimum legal requirements. }\end{array}$ & 114 & 71.25 & 2 \\
\hline 5. & $\begin{array}{l}\text { There are prevention programs in the company against disease } \\
\text { and serious health risk. }\end{array}$ & 84 & 52.5 & 4 \\
\hline & Maximum Possible Score & 160 & $100 \%$ & \\
\hline
\end{tabular}

\subsection{Indicator Set for the Professional Development and Training Dimension}

Insofar as the efforts made by companies to sustain professional development and training (see Table 5), our results show that the issue is quite problematic. In comparison with the other dimensions, the mean aggregate score obtained for this dimension shows a coverage rate of $67.5 \%$ which means that this dimension is the least represented in the reality of the companies under scrutiny. This can also be noticed by analyzing each individual indicator applied on this dimension, the relative scores being quite low (between 40 and $48 \%$ ).

Table 5. Scores registered for the professional development and training dimension.

\begin{tabular}{llcc}
\hline \multicolumn{1}{c}{ Dimension Indicators } & $\begin{array}{c}\text { Gross Total } \\
\text { Score }\end{array}$ & $\begin{array}{c}\text { Relative } \\
\text { Score (\%) }\end{array}$ & $\begin{array}{c}\text { Ranking } \\
\text { Indicator }\end{array}$ \\
\hline 1. & $\begin{array}{l}\text { The company shows interest for the evolution, and the } \\
\text { personal and spiritual development of its employees. }\end{array}$ & 71 & 2 \\
\hline $\begin{array}{l}\text { The company provides employees with inward/outward } \\
\text { services, development, and training programs in order to } \\
\text { enhance knowledge, abilities, and competencies. }\end{array}$ & 77 & 48.12 & 1 \\
\hline 3. & $\begin{array}{l}\text { The company provides employees with time off work for } \\
\text { professional development reasons. }\end{array}$ & 64 & 40 \\
\hline & Maximum Possible Score & $100 \%$ & 3 \\
\hline
\end{tabular}

\subsection{Indicator Set for Employees' Rights}

From the point of view of the mean aggregate score for the employees' rights dimension (see Table 6), the companies registered a score of 20.28 points, which means a coverage of $81.12 \%$ of the maximum score.

On the other hand, judging by the indicators that make up this dimension, the companies score the highest when it comes to protection against sexual harassment and aggression (at a proportion of approximately $61.25 \%$, a score of 98 points). At the other end, however, they register the lowest 
score for the indicator referring to the right to association and collective bargaining. We can note that the coverage rate for this indicator is not significant.

Table 6. Scores registered for the employees' rights dimension.

\begin{tabular}{llccc}
\hline \multicolumn{1}{c}{ Dimension Indicators } & $\begin{array}{c}\text { Gross Total } \\
\text { Score }\end{array}$ & $\begin{array}{c}\text { Relative } \\
\text { Score (\%) }\end{array}$ & $\begin{array}{c}\text { Ranking } \\
\text { Indicator }\end{array}$ \\
\hline 1. & The company ensures that its employees know their rights. & 92 & 57.50 & 3 \\
\hline 2. $\quad \begin{array}{l}\text { The company ensures that its employees have right to enter } \\
\text { in associations and collective bargaining. }\end{array}$ & 86 & 53.75 & 4 \\
\hline 3. $\quad$ The company respects its obligations towards its employees. & 94 & 58.75 & 2 \\
\hline & $\begin{array}{l}\text { The company provides protection against any form of } \\
\text { discrimination (workplace access, payment, promotion, } \\
\text { professional training and working conditions. }\end{array}$ & 92 & 57.50 & 3 \\
\hline 5. & $\begin{array}{l}\text { The company protects its employees against any form of } \\
\text { sexual harassment and aggression. }\end{array}$ & 98 & 61.25 & 1 \\
\hline & Maximum Possible Score & 160 & $100 \%$ \\
\hline
\end{tabular}

\subsection{Indicator Set for Internal Communication}

With respect to the fifth dimension-internal communication-the companies registered a mean aggregate score of 17.84 , which means a coverage rate of $71.37 \%$ of the maximum possible score (see Table 7). Out of the indicators that make up this dimension, the greatest emphasis is laid on informing the employees regarding the company's economic and financial situation, its direction of development, and the implementation of procedures that facilitate internal communication (a relatively similar score of $55.62 \%$ for these two indicators). Nevertheless, companies make insufficient efforts to consult their employees when making a major decision, which is something that they need to pay closer attention to.

Table 7. Scores registered for the internal communication dimension.

\begin{tabular}{llcc}
\hline \multicolumn{1}{c}{ Dimension Indicators } & $\begin{array}{c}\text { Gross Total } \\
\text { Score }\end{array}$ & $\begin{array}{c}\text { Relative } \\
\text { Score (\%) }\end{array}$ & $\begin{array}{c}\text { Ranking } \\
\text { Indicator }\end{array}$ \\
\hline $\begin{array}{l}\text { The company informs its employees regarding its } \\
\text { economic and financial situation, and its directions } \\
\text { of development. }\end{array}$ & 89 & 55.62 & 1 \\
\hline 2. $\quad \begin{array}{l}\text { The company consults its employees before taking } \\
\text { major decisions. }\end{array}$ & 71 & 44.37 & 4 \\
\hline 3. $\quad \begin{array}{l}\text { The company has set up procedures that facilitate internal } \\
\text { communication. }\end{array}$ & 89 & 55.62 & 2 \\
\hline $\begin{array}{l}\text { The company is honest and transparent in communicating } \\
\text { and exchanging information with its employees. }\end{array}$ & 88 & 55 \\
\hline The company takes into account its employees' requests \\
and disgruntlements.
\end{tabular}

As it soon becomes obvious from our respondents' answers, one of the multinational companies' chief advantages is that they provide an attractive salary, higher than the minimum wage for less qualified jobs. Our study has revealed that this phenomenon is present in almost all the companies. Despite this, however, the payment strategy is considered fair, stimulating, flexible, and transparent in two thirds of the cases we analyzed (see Figure 4). 
Apart from the 18 indicators presented above, we proposed a set of general indicators regarding the companies' responsibility towards their own employees, which were analyzed through the same methodology (see Table 8).

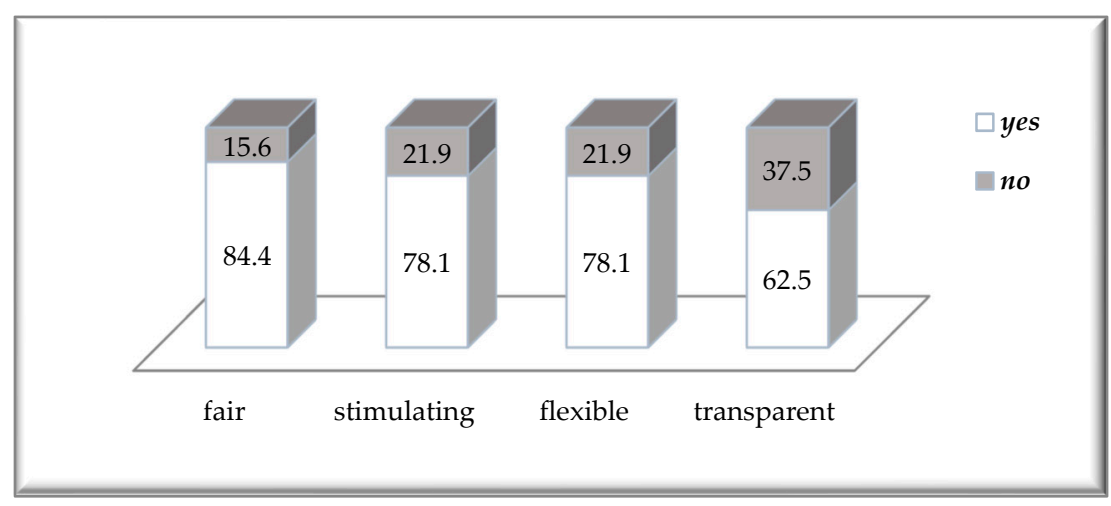

Figure 4. Perception of the companies' payment strategy.

Table 8. Scores registered for general indicators.

\begin{tabular}{|c|c|c|c|c|}
\hline & General Indicators & $\begin{array}{l}\text { Total Score per } \\
\text { Companies }\end{array}$ & $\begin{array}{l}\text { Relative } \\
\text { Score }(\%)\end{array}$ & $\begin{array}{l}\text { Ranking } \\
\text { Indicator }\end{array}$ \\
\hline 1. & $\begin{array}{l}\text { The company pays perquisites for leisure time and for its } \\
\text { employees' cultural activities. }\end{array}$ & 85 & 53.12 & 9 \\
\hline 2. & The company encourages a healthy lifestyle. & 111 & 69.37 & 6 \\
\hline 3. & $\begin{array}{l}\text { The company encourages the presence of women in } \\
\text { positions leadership. }\end{array}$ & 126 & 78.75 & 3 \\
\hline 4. & $\begin{array}{l}\text { The company advances personnel diversity (from ethnic } \\
\text { backgrounds, different cultures, religions, societies). }\end{array}$ & 125 & 78.12 & 4 \\
\hline 5. & $\begin{array}{l}\text { The company is focused in attracting talents and } \\
\text { retaining personnel. }\end{array}$ & 130 & 81.25 & 2 \\
\hline 6. & $\begin{array}{l}\text { The company encourages its employees' internal mobility } \\
\text { (the personnel's evolution on a hierarchical scale). }\end{array}$ & 130 & 81.25 & 2 \\
\hline 7. & $\begin{array}{l}\text { The company encourages its employees to participate in } \\
\text { volunteering programs. }\end{array}$ & 108 & 67.5 & 6 \\
\hline 8. & The company acknowledges and appreciates thorough work. & 126 & 78.75 & 3 \\
\hline 9. & $\begin{array}{l}\text { The company manifests empathy and offers assistance for its } \\
\text { employees' personal problems. }\end{array}$ & 133 & 83.12 & 1 \\
\hline 10. & $\begin{array}{l}\text { The company provides its employees with the possibility of } \\
\text { striking a balance between their work and family/personal life. }\end{array}$ & 117 & 73.12 & 5 \\
\hline 11. & $\begin{array}{l}\text { The company provides its redundant employees with } \\
\text { professional reorientation courses. }\end{array}$ & 77 & 48.12 & 10 \\
\hline 12. & $\begin{array}{l}\text { The company provides counselling services when employees } \\
\text { change jobs or retire. }\end{array}$ & 85 & 52.5 & 9 \\
\hline 13. & $\begin{array}{l}\text { The company has developed activities that foster the relationship } \\
\text { between family members and the organization. }\end{array}$ & 88 & 55 & 8 \\
\hline \multirow[t]{2}{*}{14.} & $\begin{array}{l}\text { The company provides its employees with financial and/or } \\
\text { social assistance. }\end{array}$ & 98 & 61.25 & 7 \\
\hline & Maximum Possible Score & 160 & $100 \%$ & \\
\hline
\end{tabular}

As we can note in the table above, based on each indicator's score, the features that multinational companies pay closest attention to are: "The company manifests empathy and offers help for its employees' personal problems" (1st place), “The company encourages its employees' internal mobility 
(the personnel's evolution on a hierarchical scale)" (2nd place), and "The company acknowledges and appreciates thorough work" (3rd place).

Based on the scores above, the features that still need improvement are as follows:

- The company provides its redundant employees with professional reorientation courses (10th, and last, place).

- The company provides counselling services when employees change jobs or retire (9th place).

- The company pays perquisites for leisure time and for its employees' cultural activities (9th place).

- The company has developed activities that foster the relationship between family members and the organization (8th place).

For these indicators, the maximum possible score is of 70 points. On average, the companies scored around 48.06 , which represents a coverage of $69 \%$ of the maximum possible score. The coverage rate is of $68.66 \%$.

The most widespread incentives in the companies we studied are presented in Table 9.

Table 9. List of incentives.

\begin{tabular}{lc}
\hline \multicolumn{1}{c}{ Incentives } & $(\mathbf{\% )}$ \\
\hline 1. Meal vouchers & 93.8 \\
2. Free medical checkup & 87.5 \\
3. Gifts for different occasions & 84.4 \\
4. Company-paid group activities & 68.8 \\
5. Sports-related facilities and discounts & 65.6 \\
6. Obtaining advantageous credits at various banks & 65.6 \\
7. Insurance contributions (life, health, private pensions) & 56.3 \\
8. Cafeteria/catering & 56.3 \\
9. Free transportation from home to work & 56.3 \\
10. Discounts for certain products & 56.3 \\
11. Learning a foreign language for free & 50 \\
12. Discounts for certain services, other than the ones mentioned above & 40.6 \\
13. Buying shares in the company & 18.8 \\
\hline
\end{tabular}

From a human resources point of view, responsibility towards employees entails competitive salaries and a system of motivating incentives, unbiased working conditions, and respecting one's obligation towards one's employees in an optimum legal framework. Additionally, there are policies for safeguarding employees' health and their work safety. Besides these elements-which most companies abide by-there are concerns for making internal communication more transparent and efficient on as many organizational levels as possible.

Fostering a climate suitable for personal and professional growth remains a sensitive topic, which is only present in two thirds of the companies included in the study. These organizations must make greater efforts in providing their employees with such growth and development opportunities inside the company. This would result in a higher degree of employee retention and higher indirect, long-term profit.

In order to ensure a proper environment for their employees and to meet all their concerns (be they ethical, social, or environmental), a few of the companies in our studies have set up special departments, such as the Business Partners Department, for instance, who deal only with the employees' problems. Other instruments companies use to monitor the interests of their employees are online, internal questionnaires; focus groups; workshops; and discussions on certain topics. At the same time, we have also identified social, cultural, and environmental activities inside these companies, manifesting social responsibility towards the company's stakeholders, namely programs of engagement and wellbeing at work, volunteering programs, sports and teambuilding programs, but also professional development training programs, competitions, social and cultural activities. 
According to our respondents' answers, volunteering programs are quite a frequent occurrence and they are part of the companies' policy, generating, for the most part, positive feedback from the employees. There are, however, instances where the employees are less receptive to such programs. Although in certain contexts various activities (cleaning, environment protection, social volunteering for the disadvantaged during the holidays, etc.) do take place in the companies, social responsibility strategies are absent.

In our analysis, we have taken into account the percentage of the coverage rate in order to assess the social responsibility that the companies manifest towards their own employees. Thus, we considered the following percentages as benchmarks for understanding the situation of social responsibility phenomenon:

1. Under $25 \%$-we cannot talk about companies manifesting social responsibility towards their own employees.

2. Between $25 \%$ and $50 \%$ - companies manifest a generally low level of social responsibility that does not meet the interests of most employees.

3. Between $50 \%$ and $75 \%$-the companies' policies include a sound ethical component, clearly defined ethical standards, which they champion and monitor.

4. Over $75 \%$ - the companies have impeccably ethical and proactive behaviour, and a high level of social responsibility regarding their human resources.

Starting from the coverage rates of the HRCSR dimensions in the study, as expressed in Table 10, we can note that out of the five dimensions, three fall in the middle category (coverage of 50 to $75 \%$ ), while other two reach the upper category of social responsibility (over 75\%) (see Figure 5).

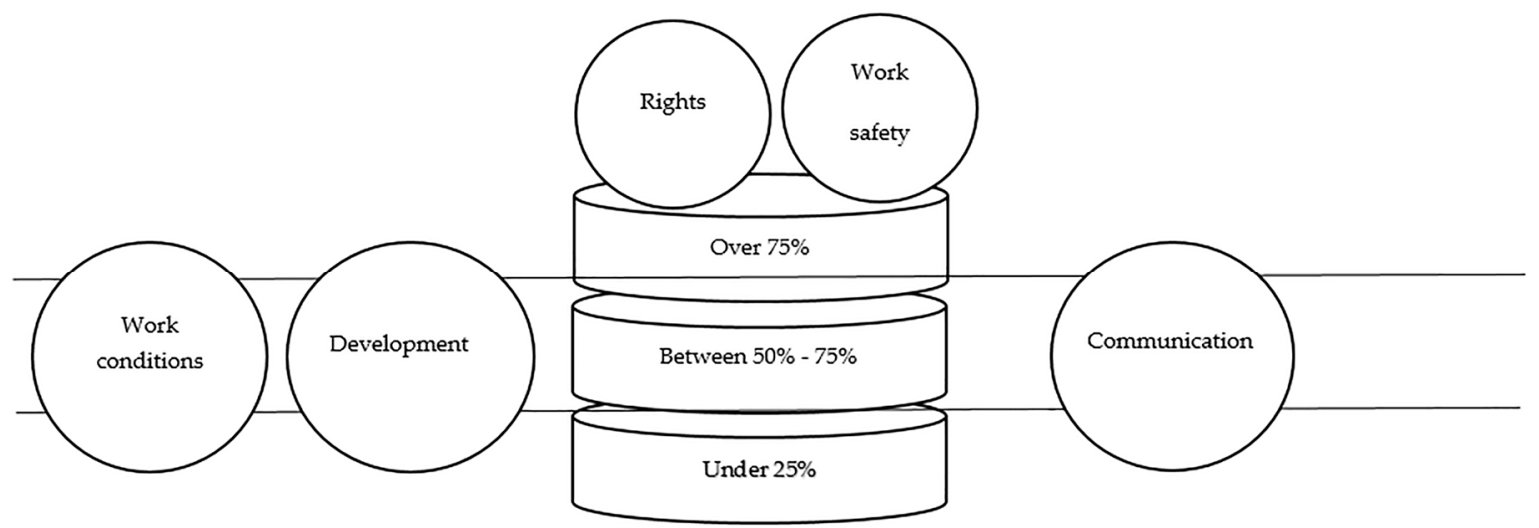

Figure 5. Graphical representation of the percentages of HRCSR manifestations, on dimensions.

Table 10. Synoptic table with the main dimensions' coverage rates.

\begin{tabular}{lccccc}
\hline & $\begin{array}{c}\text { Work } \\
\text { Conditions }\end{array}$ & $\begin{array}{c}\text { Health and } \\
\text { Safety }\end{array}$ & $\begin{array}{c}\text { Development } \\
\text { and Training }\end{array}$ & Rights & $\begin{array}{c}\text { Internal } \\
\text { Communication }\end{array}$ \\
\hline Coverage rate (\%) & 72.12 & 80.25 & 67.50 & 81.12 & 71.37 \\
\hline
\end{tabular}

\section{Conclusions}

Starting with the 1990s, all the way into the 2000s, in Romania, people used the phrase "corporate social responsibility," at a time when the concept was exclusively the prerogative of multinational companies. At the beginning of their activity on the Romanian market, these branches imported the culture and organizational practices of the parent company. 
Even though commercial motivation dominated initially, at present, multinational and big companies are starting to develop a CSR history and have set up a strategic approach, some having had almost a decade, or even more, to foster such a culture of responsible engagement (with all the necessary instruments: codes of conduct, management standards, social investments, reports [27], etc.). These companies are going through a qualitative development stage, in which contents have begun to fall into place so that we can talk about sustainable business practices. The campaigns and projects that have taken place in Romania over the past three years [36], advancing the idea of durable development, are mostly due to the efforts of multinational companies.

From the point of view of these companies' efforts for their employees, or the perspective of social responsibility coming to the aid of its own human resources, our study reveals significant concern for providing good working conditions, health and safety, professional development opportunities, unbiasedness, and efficient and transparent communication. As expected, the multinational companies have become aware of the fact that their employees are one of the main stakeholders of social responsibility. Other major concerns for these companies include encouraging the personnel's evolution in the company's hierarchy, and promoting women in leadership positions (gender equality). At the same time, the companies in our study revealed interest in diversifying their employee pool (from ethnic backgrounds, different cultures, religions, societies). We found out that the companies have impeccably ethical and proactive behaviour, and a high level of social responsibility regarding their human resources, especially in connection to the employees' rights and work safety.

If we refer to the stages of organizational development, as identified by Schneider and Barsoux [37], in their evolution, multinational companies in Romania have overcome their legalistic stage, where responsibility meant just respecting legal norms. Out of all the dimensions of social responsibility, as analyzed in this paper, the one about respecting the employees' rights is the best effected (a coverage rate of 81.12 , according to the synoptic Table 10).

Most companies understood that the employees' rights have to be respected, and there is a careful effort to protect these rights. They manifest a high social responsibility inside this dimension (over $75 \%$ ). The big corporations of Romania have doubtlessly evolved towards ethical development stages, in which they comprehend the necessity for social responsibility for their employees, and for the social environment in which they operate. Companies have clearly defined ethical standards and benchmarks; the organizational culture has become proactive by working to preempt social problems.

From our point of view, based on the above-mentioned classification [37], the stage which multinational companies find themselves at is that of emerging ethical organizations (from the point of view of the working conditions, organizational development and training, and communication with the employees). We find ourselves in the situation where we have clearly defined ethical standards as far as human resources are concerned, which the companies are trying to impose, but practically there are small omissions and improvable behaviors (vulnerable points). However, there are also features (the employees' rights dimension, and the health and safety dimensions) that make them come across as mature ethical organizations, with long-term responsibility strategies, with a good image, and a constant reputation due to the way they deal with their own employees.

Multinational companies from the automotive sector are aware that, long-term, CSR effects a series of advantages, outwards-enhancing the company's reputation and consolidating its employer's brand, its competitive advantage on the market, its media visibility—as well as inwards-fostering an organizational culture that may generate a greater engagement from its own employees, and financial advantages.

There are, therefore, responsible organizational behaviors in the multinational companies of Romania, however they are not sufficiently integrated in Romanian literature. There is also no personalized use of the CSR concept. The companies' responsibility activities continue to be oriented more outwards than inwards. We expect CSR in Romania to undergo a process of developing HRCSR practices in other local companies as well. In small and medium-sized enterprises, CSR projects are few and far in between, and externally-oriented actions predominate, which translates into a mere 
PR objective, rather than an ethical motivation. Secondly, we anticipate a qualitative development generated by an increase in these organizations' responsible behavior towards their own employees.

The article's main contribution is that it approaches an infrequently studied problem in an expanding sector in Romania (a human resources point of view on the organizations' socially responsible behavior in the spirit of the extended CSR concept (HRCSR)). As future research directions of this problem, we will extend the research area towards companies that carry out their activities in other economic sectors, and in other regions of Romania (quantitative research), thus overcoming the limitations of the current study, based exclusively on qualitative research. Another possible research direction is the perspective of the companies' employees.

Author Contributions: All authors contributed equally to this work. All authors have read and approved the final manuscript.

Conflicts of Interest: The authors declare no conflict of interest.

\section{References}

1. Söderberg, S. ISO 26000 Guidance on Social Responsibility; AMAP: Stockholm, Sweden, 2012.

2. European Commission. A Renewed EU Strategy 2011-2014 for Corporate Social Responsibility. Available online: http://www.europarl.europa.eu/meetdocs/2009_2014/documents/com/com_com(2011)0681_ /com_com(2011)0681_en.pdf (accessed on 12 February 2018).

3. Voegtlin, C.; Greenwood, M. Corporate social responsibility and human resource management: A systematic review and conceptual analysis. Hum. Resour. Manag. Rev. 2016, 26. Available online: https:/ / papers.ssrn. com/sol3/papers.cfm?abstract_id=2716146 (accessed on 23 November 2017). [CrossRef]

4. Nikolaou, I.E. A framework to explicate the relationship between CSER and financial performance: An intellectual capital-based approach and knowledge-based view of firm. J. Knowl. Econ. 2017, 1-20. [CrossRef]

5. Russo, M.V.; Fouts, P.A. A resource-based perspective on corporate environmental performance and profitability. Acad. Manag. J. 1997, 40, 534-559. [CrossRef]

6. Bhattacharya, C.B.; Sen, S.; Korschun, D. Using corporate social responsibility to win the war for talent. Sloan Manag. Rev. 2008, 49, 37-44.

7. Branco, M.C.; Rodrigues, L.L. Corporate social responsibility and resource-based perspectives. J. Bus. Ethics 2006, 69, 111-132. [CrossRef]

8. Baek, P.; Kim, N. Exploring a theoretical foundation for HRD in society: Toward a model of stakeholder-based HRD. Hum. Resour. Dev. Int. 2014, 17, 1-15. [CrossRef]

9. Scherer, A.G.; Palazzo, G.; Matten, D. The business firm as a political actor: A new theory of the firm for a globalized world. Bus. Soc. 2014, 53, 143-156. [CrossRef]

10. Garavan, T.N.; McGuire, D. Human resource development and society: Human resource development's role in embedding corporate social responsibility, sustainability, and ethics in organizations. Adv. Dev. Hum. Resour. 2010, 12, 487-507. [CrossRef]

11. Mirvis, P. Employee engagement and CSR: Transactional, relational, and developmental approaches. Calif. Manag. Rev. 2012, 54, 93-117. [CrossRef]

12. Dinamica și Perspectiva Domeniului de CSR în România. 2017. Available online: https:/ /www.csrmedia.ro/ studii-csr/ (accessed on 9 February 2017).

13. Theazores.ro Romania CSR Index 2017. Available online: https:/ / www.theazores.ro/romania-csr-index (accessed on 9 February 2018).

14. Basu, K.; Palazzo, G. Corporate social responsibility: A process model of sensemaking. Acad. Manag. Rev. 2008, 33, 122-136. [CrossRef]

15. Campbell, J.L. Why would corporations behave in socially responsible ways? An institutional theory of corporate social responsibility. Acad. Manag. Rev. 2007, 32, 946-967. [CrossRef]

16. Carroll, A.B. Corporate social responsibility: Evolution of a definitional construct. Bus. Soc. 1999, 38, 268-295. [CrossRef]

17. United Nations Economic Commission for Europe (UNECE). Sustainable Development-Concept and Action. 2005. Available online: http:/ /www.unece.org/oes/nutshell/2004-2005/focus_sustainable_development. html (accessed on 17 October 2017). 
18. Dyllick, T.; Hockerts, K. Beyond the business case for corporate sustainability. Bus. Strateg. Environ. 2002, 11, 130-141. [CrossRef]

19. Cohen, E. CSR for HR. A Necessary Partnership for Advancing Responsible Business Practices; Greenleaf Publishing Limited: Yorkshire, UK, 2010.

20. Strandberg Consulting. The Role of Human Resource Management in Corporate Social Responsibility. 2009. Available online: https:/ / corostrandberg.com/wp-content/uploads/2009/12/csr-hr-management. pdf (accessed on 23 November 2017).

21. Cohen, E. Responsabilitatea Socială Corporatista in Sprijinul Resurselor Umane; Editura Curtea Veche: București, Romania, 2011.

22. KPMG. The KPMG Survey of Corporate Responsibility Reporting 2015. Available online: https:/ /home.kpmg.com/ xx/en/home/insights/2015/11/kpmg-international-survey-of-corporate-responsibility-reporting-2015.html (accessed on 5 June 2017).

23. Baleanu, T.E.; Chelcea, L.; Stancu, A. The social responsibility of the top 100 Romanian companies. An analysis of corporate websites. Amfiteatru Econ. J. 2011, 13, 237-250.

24. CSR Trends and Realities in Romania. 2013. Available online: www.csrmedia.ro (accessed on 12 December 2017).

25. Dura, C.; Drigă, I. The impact of multinational companies from Romania on increasing the level of corporate social responsibility awareness. Contemp. Econ. 2016, 10. [CrossRef]

26. Gherghina, S.C.; Vintila, G. Exploring the impact of corporate social responsibility policies on firm value: The case of listed companies in Romania. Econ. Sociol. 2016, 9, 23-42. [CrossRef] [PubMed]

27. Guse, R.G.; Almasan, A.; Circa, C.; Dumitru, M. The role of the stakeholders in the institutionalization of the CSR reporting in Romania. Account. Manag. Inf. Syst. 2016, 15, 304-340.

28. Hategan, C.D.; Curea-Pitorac, R.-I. Testing the correlations between corporate giving, performance and company value. Sustainability 2017, 9, 1210. [CrossRef]

29. Iamandi, I.E. Responsabilitatea Socială Corporativă în Companiile Multinaţionale; Editura Economică: Bucureşti, Romania, 2010.

30. Ivascu, L.; Cioca, L.I.; Rus, S. Sustainable Development Influence on the Competitive Advantage of Companies. In Proceedings of the 27th IBIMA Conference, Milan, Italy, 4-5 May 2016.

31. Obrad, C.; Petcu, D.; Gherheș, V.; Suciu, S. Corporate social responsibility in Romanian companies-Between reality and perceptions. Amfiteatru Econ. J. 2011, 12, 43-55.

32. Suciu, S.; Gherheş, V.; Petcu, D. Corporate social responsibility-A conceptual approach. An. Ser. Ştiinţe Econ. Timiş. 2010, 16, 844-849.

33. Bauman, C.W.; Skitka, L.J. Corporate social responsibility as a source of employee satisfaction. Res. Organ. Behav. 2012, 32, 63-86. [CrossRef]

34. Glavas, A.; Kelley, K. The effects of perceived corporate social responsibility on employees. Bus. Ethics Q. 2014, 24, 165-202. [CrossRef]

35. Remišová, A.; Búciová, Z. Measuring corporate social responsibility towards employees. J. East Eur. Manag. Stud. 2012, 17, 273-291. Available online: https://www.econstor.eu/handle/10419/84069 (accessed on 15 November 2017).

36. Obrad, C. Responsabilitatea Socială a Companiilor din România; Editura Prouniversitaria: București, Romania, 2015.

37. Schneider, S.; Barsoux, J.-L. Managing across Cultures; Prentice Hall: London, UK, 1997.

(C) 2018 by the authors. Licensee MDPI, Basel, Switzerland. This article is an open access article distributed under the terms and conditions of the Creative Commons Attribution (CC BY) license (http://creativecommons.org/licenses/by/4.0/). 